\title{
電気泳動法による血清蛋白質分画定量法の標準操作法集
}

\author{
電気泳動学会標準操作法小委員会
}

電気泳動学会では，電気泳動法による血清蛋白質の分画定量法を標準化することが，研究検査上に与 える便宜を考えて Tiselius 法, 汇紙電気泳動法についてはすでに標準操作法を発表してきた。

今回セルローズアセテート電気泳動法についても検討を加え, 標準操作法が決定された。Tiselius 電 気泳動法おるび汇紙電気泳動法の標準操作法が制定されたのは, それぞれ 1950年 扰よび 1958 年であっ て，てれらはいずれも一部改訂の必要があるてとがかねてから指摘されていた。

そてでセルローズアセテート電気泳動法の標準操作法の制定の機会に, てれまでのむのにあ改訂を加 えてあわせて印刷し，電気泳動実験を掞となう人々の便宜をはかることにした。

\section{Tiselius 電気泳動法による血清蛋白分画定量法の標準操作法}

1. 光学系は電気泳動をおてなうセル内の屈折率勾配または屈折率をシュリーレン法または干渉法をむちいて記録 するむのを用いる。セルの大きさはとくに規定しない。

2. 緩衝液は, 燐酸緩衝液 $(\mathrm{pH} 7.9,0.05 \text { モル) })^{1)}$ またはベロナールーベロナールソーダ緩衝液 $(\mathrm{pH} 8.6$, イオン強 度 0.1$)^{2)}$ を用いる。

3. 電気泳動は上記の緩衝液に対して十分透析した血清について おてなう。泳動時の蛋白濃度は 1.5 ないし 2.0 $\mathrm{g} / \mathrm{d} l$ とする。

4. 電気泳動をおこなうときの温度，電流，時間などは特に規定しない。血清蛋白分画が十分分離するような条件 で電気泳動を抗てなう。

5. 電気泳動図は写真撮影により記録し，測定はこの写真またはそれを据大したむのについておこなうことを原則 とする゙)。

6. 蛋白分画百分率は 上昇側および下降側の両方につい:て測定しその両方および平均值を記載することが望まし $\left(\lambda^{4)}\right.$ 。

7. 下降側のアルブミンの界面の移動速度と泳動を行なった試料の比伝導度からアルブミンの易動度を求める5)。 各蛋白分画の易動度は上昇側の界面から求めた各蛋白分画の移動速度の比と上記のようにして求めたアルブミンの易 動度加算出する。

注1）燐酸缓衝液は 0.05 モルの $\mathrm{Na}_{2} \mathrm{HPO}_{4}$ と 0.05 モルの $\mathrm{KH}_{2} \mathrm{PO}_{4}$ を $16: 1$ の 容積比で混合したむので，そのイ オン強度は 0.144 である。

注2） $20.6 \mathrm{~g}$ ベロナールソーダと $3.68 \mathrm{~g}$ のベロナールを水にとかして $1 l$ としたあのである。

注3） Antweiler の装置による分析む標準操作法に含ませることにする。

注4）通常上昇側怙よび下降側からえられる蛋白分画百分率に大差はない。分析結果には少なくとも分析を拉てな った装置，緩衝液の種類および結果がどの界面を用いてえられたものかを附記するととが望ましい。

注5）アルブミンの易動度 uは次式により求める。

$\mathrm{u}=\frac{\mathrm{d} / \mathrm{t}}{\mathrm{i} / \mathrm{KS}} \quad \mathrm{cm}^{2} /$ volt $\bullet \mathrm{sec}$

ただし $\mathrm{d}:$ 下降側でのアルブミン界面の移動距離 $(\mathrm{cm})$

$\mathrm{t}:$ 通電時間 $(\mathrm{sec})$

$\mathrm{i}:$ 平均電流 $(\mathrm{amp})$

$\mathrm{K}$ ：泳動に供した試料の泳動時の温度での比伝導度 $\left(\mathrm{mho} \cdot \mathrm{cm}^{-1}\right)$

$\mathrm{S}$ : セルの断面積 $\left(\mathrm{cm}^{2}\right)$ 


\section{沪紙電気泳動法による血清蛋白分画定量法の標準操作法}

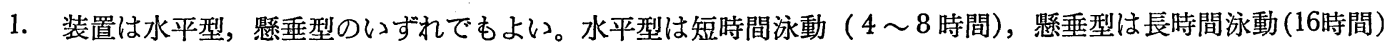
に適している。

2. 汇紙は東洋汇紙 No. 51 がよいが，No. 51 A であ，Whatman No.1であさしつかえない。汇紙の大きさはとく に規定しない。

3. 緩衝液はべロナール, ベロナールソーダ緩衝液を用いる。

水平型の場合は $\mathrm{pH} 8.6, \mu=0.05$

奬垂型の場合は $\mathrm{pH} 8.6, \mu=0.075$ の緩衝液がよい。

4. 試料は汇紙巾 $1 \mathrm{~cm}$ について，アミドブラック $10 \mathrm{~B}$ 染色には血清 $0.0025 \mathrm{ml}$, BPB 染色には $0.005 \mathrm{ml}$ をバン ド状につける。

5. 泳動条件は BPB を加えた血清アルブミンが原点より $6 \sim 8 \mathrm{~cm}$ 移動するのを標準とし, 電圧, 電流, 泳動時間 はとくに規定しない。

6. 泳動後乾燥器で乾燥 $\left(100 \pm 5^{\circ} \mathrm{C}, 20\right.$ 分間)

7. 染色はアミドブラック $10 \mathrm{~B}(\mathrm{AS}), \mathrm{BPB}$ のいずれでむよい。

i） AS の場合はメタノール，承酿酸 $(9: 1)$ 亿S $0.2 \%$ の割合にとかし，ての中に沪紙を 20 分間浸して染 色する。

脱色は $2 \%$ 酶酸水で10分，10分，30分，10〜20 時間の順序で行なう。

ii） $\mathrm{BPB}^{1)}$ の場合は，次の処方のものがすすめられる。

$\mathrm{BPB} 1.0 \mathrm{~g}$ ，エタノール $100 \mathrm{~m} l$ ，氷酢酸 $200 \mathrm{~m} l$ ，昇永 $1.0 \mathrm{~g}$ ，水を加えて $1 l$ とする。

20 分間染色ののち，1\%临酸水で，5 分，5 分，10 分間脱色する。

8. デンシトメトリー：透明化はパラフィンを加熱溶解し， $130^{\circ} \mathrm{C}$ になったとき，ての中に汇紙を入れ，気泡のな くなるのを標準としてとり出す，又は，流動パラフィンを用いる。

AS 染色の場合は $610 \mathrm{~m} \mu, \mathrm{BPB}$ 染色の場合は $600 \mathrm{~m} \mu$ の波長で，巾 $1 \mathrm{~mm}$ のスリットを用い測定する。

デンシトメーターは, 光学密度直線性のあのを用いる。

9. 分画別抽出法： BPB 染色標本を分画どとに切りとって，それぞれ一定量（アルブミン分画のみ $10 \mathrm{ml}$ ，その他 の分画 $5 \mathrm{ml}$ ) の $0.01 \mathrm{~N} \mathrm{NaOH，又は} 0.02$ モル $\mathrm{NaHCO}_{3}$ で 1 時間抽出する。抽出液について $580 \sim 640 \mathrm{~m} \mu$ の波長で 比色定量する。比色のブランクは沪紙の染色されていない部分の $1 \mathrm{~cm}$ を同様に処理したすのを用いる。

注1） ベックマン・スピンコの装置を用いて泳動し，アナリトロールでデンシトメトリーを行なうときは，指定さ れたとおりの泳動を行ない，所定の染色液で，指示されたと招りに染色，脱色を行なわなければならない。 


\section{セルローズ・アセテート電気泳動法による血清蛋白分画定量法の標準操作法1)}

1. 泳動箱：泳動箱の空間 $1000 \mathrm{~cm}^{3}$ につき緩衝液面の総表面積が膜面抽よび汇紙面を含めて， $200 \mathrm{~cm}^{2}$ 以上の密 閉箱を用(るる2)。

2. 膜の長さは， 5 ないし $6 \mathrm{~cm}$ を標準とする。膜巾は特に規定しないが，血清塗布バンドの長さは，デンシトメ

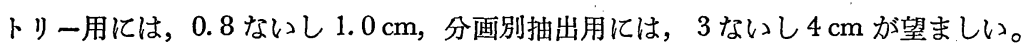

3. 緩衝液：ベロナールーベロナール・ソーダ緩衝液 $(\mathrm{pH} 8.6 ， 0.06$ ないし 0.07 モル) を用いる。

4. 血 清: 膜巾 $1 \mathrm{~cm}$ につき, デンシトメトリー用には 0.4 ないし $0.8 \mu l^{3)}$ 分画別抽出用には 0.6 ないし 1.2 $\left.\mu l^{3}\right)$ を定量用ピペットにより,バンド状につける。

5. 通 電：膜巾 $1 \mathrm{~cm}$ につき， 0.4 ないし $0.8 \mathrm{~mA}$ の一定電流で，アルブミン分画の先端から， $\gamma$ アグロブリン分 画の後端までが 3 ないし $4 \mathrm{~cm}$ の長さに展開するまで通電する。

6. 染 色：ポンソー $3 \mathrm{R}$ を 6 \%のトリクロル酢酸水溶液に，0.4 ないし $0.8 \% 4)$ 亿とかしたすので，1 分 30 秒 ないし 3 分染色する。

7. 脱 色： 1 ないし $3 \%$ 酶酸水溶液で，1 ないし 2 分ずつ 4 ないし 5 回，洗液が着色しなくなるまでおてなう。

8. デンシトメトリー： 流動パラフィンまたはデカリンなどで透明化した泳動標本につき， 490 ないし $540 \mathrm{~m} \mu$ の 波長 ${ }^{5}$ で, 巾 $1 \mathrm{~mm}$ 以下のスリットを用いて着色バンドの中央部で測定する。デンシトメーターは，光学密度直線性 のものを用いる。

9. 分画別抽出法： 泳動標本を分画でとに切り取って，それぞれなるべく小量 $(3.5$ ないし $5 \mathrm{~m} l)$ の一定量の $0.01 \mathrm{~N} \mathrm{NaOH}$ で 5 ないし 10 分間, 摇り動かしながら抽出し, 抽出液につき, 490 ないし $540 \mathrm{~m} \mu$ の波長 5 で比色榊 量する。此色のブランクは，膜の染色されていない部分の $1 \mathrm{~cm}$ を同様に処理したものを用いる。

注1）現在最む広く用いられている長さ5ないし $6 \mathrm{~cm}$ のセルローズアセテート（オキソイド・セパラックス・ミ リポア・メンブランフォリンなど）を用いて血清蛋白分画を扣てなう実験法を対象とした標準操作法である。

てれ以外の方法については，標準操作法小委員会での検討がすみ次第，逐次標準操作法を発表する。

注2）セルローズ・アセテート膜は薄いから, 箱内湿度の維持いかんが分析成績に影響する。

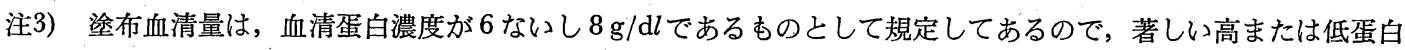
血清に対しては，濃度に応じて血清叙布量を変える必要がある。

注4）膜自体の着色を防ぐためには，オキソイドに対しては，ポンソー $3 \mathrm{R}$ 濃度は $0.4 \%$ を用いる。

注5）波長巾の狭いフィルター，例えば干渉フィルターを用いることがのぞましい。 